Sains Malaysiana 49(4)(2020): 839-846

http://dx.doi.org/10.17576/jsm-2020-4904-13

\title{
Potential Association of Nicotinamide on the Telomerase Activity and Telomere Length Mediated by PARP-1 Mechanism in Myeloid Cancer
}

(Potensi Perkaitan Nikotinamida ke atas Aktiviti Telomerase dan Panjang Telomer Disebabkan oleh Mekanisme PARP-1 pada Kanser Mieloid)

\author{
Nur Rasyidah Muhammad, Azlina Ahmad, Siti Norasikin Mohd Nafi, Farizan Ahmad, ZariYAntey \\ ABDUL HAMID \& SARINA SULONG*
}

\begin{abstract}
Administration of nicotinamide is affecting various types of cells through its survival, maturation, and differentiation. Nicotinamide as part of vitamin B3, plays an important role in DNA repair and maintenance of the genomic stability which related to its function as a NAD+ precursor that involve in many biological processes. During DNA breaks, PARP-1 mechanism will be activated and use NAD + as a substrate in process of DNA damage and repair that will result to either cell repair and cell death. In the meantime, in presence of nicotinamide that is also acting as a PARP-1 inhibitor, causing inability of the repair mechanism to fix the entire DNA damage which also lead to the cell death. Therefore, loss of PARP-1 enzyme will cause disturbance in the DNA repair process. Telomere shortening rate was reduced in the presence of nicotinamide that might related with telomerase enzyme which able to maintain the telomere length of the cell. Other than that, telomere also can be influenced by PARP-1 activity where it might show some correlation between nicotinamide, telomere and telomerase that could related with PARP-1 mechanism. Currently, there is no treatment options that respond effectively in chronic myeloid leukemia (CML) in blast crisis (BC) phase without any side effect and it is require an identification of new drug therapies to treat the CML patients. By understanding the role and potential of nicotinamide relation with PARP-1 mechanism in telomere and telomerase status may improve the therapeutic strategy for chronic myeloid leukemia.
\end{abstract}

Keywords: Nicotinamide; PARP-1; telomerase; telomere

\section{ABSTRAK}

Pengambilan nikotinamida menjejaskan pelbagai jenis sel melalui kelangsungan hidup, kematangan dan pembezaannya. Nikotinamida sebagai sebahagian daripada vitamin B3 memainkan peranan penting dalam pembaikan dan penyelenggaraan kestabilan genom DNA yang berkaitan dengan fungsinya sebagai prakursor NAD+ yang melibatkan banyak proses biologi. Semasa DNA pecah, mekanisme PARP-1 akan diaktifkan dan menggunakan $N A D+$ sebagai substrat dalam proses kerosakan dan pembaikan DNA yang akan menyebabkan pembaikan sel dan kematian sel. Sementara itu, dengan adanya nikotinamida yang juga bertindak sebagai perencat PARP-1, menyebabkan ketidakupayaan mekanisme pembaikan untuk memperbaiki keseluruhan kerosakan DNA yang juga membawa kepada kematian sel. Oleh itu, kehilangan enzim PARP-1 akan menyebabkan gangguan dalam proses pembaikan DNA. Kadar pemendekan telomer berkurang dengan kehadiran nikotinamida yang mungkin berkaitan dengan enzim telomerase yang dapat mengekalkan panjang telomer sel. Selain itu, telomer juga boleh dipengaruhi oleh aktiviti PARP-1 dan ia mungkin menunjukkan beberapa korelasi antara nikotinamida, telomer dan telomerase yang boleh dikaitkan dengan mekanisme PARP-1. Pada masa ini, tiada pilihan rawatan yang bertindak balas dengan berkesan dalam leukemia mieloid kronik (CML) dalam fasa krisis blas (BC) tanpa sebarang kesan sampingan dan memerlukan pengenalan terapi ubat baru untuk merawat pesakit CML. Dengan memahami peranan dan potensi hubungan nikotinamida dengan mekanisme PARP-1 dalam telomer dan status telomerase dapat meningkatkan strategi terapeutik untuk leukemia mieloid kronik.

Kata kunci: Nikotinamida; PARP-1; telomerase; telomer

\section{INTRODUCTION}

Nicotinamide or known as niacinamide or nicotinic acid amide is an active form of vitamin B3 which is also a water soluble amide of nicotinic acid with many physiological and pharmacological functions in various organisms. It acts as precursors of nicotinamide adenine dinucleotide (NAD) (Audrito et al. 2011) which is an important molecule involve in energy metabolism and also in chemical 
reaction in the body including ADP-ribosylation that related to DNA repair, cell death, transcription, DNA replication, and cell cycle (Ida et al. 2009). Nicotinamide has also shown to be a free radical scavenger and been used in cyclic ADP ribose synthesis (Surjana et al. 2010) and its phosphorylated derivative, nicotinamide adenine dinucleotide phosphate (NADP+). The dietary sources of nicotinamide and niacin are readily available in plant and animal food such as in liver, yeast, dairy product, bean, green vegetable, bread and coffee. NAD + and NADP + can be enzymatically hydrolyzed to nicotinamide from the uncooked food during the process of cooking (Jacob \& Swendseid 1996).

Nicotinamide have been used for years by many people and it was shown to have low toxicity and side effects (Knip et al. 2000). Deficiency of nicotinamide in human can cause pellagra (Bogan \& Brenner 2008) which is a nutritional disorder to cause dermatitis, diarrhea, dementia, and also death (Karthikeyan \& Thappa 2002). It also had been used in the therapy of pellagra even in high levels of the drugs. According to Paul (2011), nutrient deficiency such as folate, zinc and magnesium, can cause the DNA damage from various causes possibly results to shorter telomeres in rats and cells.

Cancer patients were found to be at risk of niacin deficiency in a few studies due to the suppressed $\mathrm{NAD}+$ levels from chemotherapy and maintaining an optimum level of nicotinamide is therefore important to these patients (Surjana et al. 2010). On the other hand, nicotinamide also functions as sensitizing agent and counteract chemotherapy and radiation therapy by increasing blood flow that will allow the elevated oxygen supply to the tumors (De Soto et al. 2006). Thus, tumors hypoxia is reduced.

Based on the study by Chen et al. (2015), this one type of vitamin B3 has also been shown to have the ability to preserve from the effects caused by the UV radiation and thus decrease the proportion for new premalignant skin cancer. They have found that nicotinamide has reduced the rate of various type of skin cancers when treated with nicotinamide from $11-30 \%$ compared to other type of treatment and no evidence benefit after discontinuation of nicotinamide. They also have come to agree that the intake of oral nicotinamide was safe and effective to be used in the treatment of high-risk patient of skin cancer. UV radiation can cause damage to DNA, disturb the immunity system (Yarosh 2004) and depleting the cellular ATP thereby inhibiting the DNA repair (Park et al. 2010). The production of ATP that can be used for DNA repair requires $\mathrm{NAD}+$ which can be obtain from nicotinamide that also act as a precursor of NAD + . Therefore, glycolytic blockade, ATP depletion and also the level of immunosuppression caused directly by the UV radiation can be reduced and prevented by nicotinamide (Park et al. 2010; Surjana et al. 2013; Thompson et al. 2014; Yarosh 2004). Nicotinamide has been proven to play a beneficial role in inhibiting liver fibrosis in rats and at the same time able to induce apoptosis by reducing the expression in cell cycle related proteins (Jin et al. 2011; Traister et al. 2005).

Over years, nicotinamide has been used within required doses with minimal side effect that does not cause flushing, itching, hypotension or headaches under doses of consumption (Knip et al. 2000; Ranchoff \& Tomecki 1986). Nicotinamide is also an inexpensive supplement that widely accessible in any pharmacies which can be taken as an additional supplement for consumption.

Moreover, nicotinamide also play an important role in poly (ADP-ribose) polymerase (PARP-1) which has a part in reassembling the DNA strand breaks caused by radiation and chemotherapy (Kjellen et al. 1985). Its function as $\mathrm{NAD}+$ precursor and also a substrate for PARP1 has been an important player in DNA repair and also maintenance of the genomic stability as the increase of $\mathrm{NAD}+$ level by addition of nicotinamide will also increase and improve the capacity in DNA repair. It has been studied that a certain amount of nicotinamide increase the intracellular NAD + and enhance the repair of DNA damage in cultured primary human mammary epithelial cells (Jacobson et al. 1999). It is essential to have adequate $\mathrm{NAD}+$ for the increase in ADP-ribose polymer metabolism due to the DNA damage. Hence, it showed that increasing level of NAD + by addition of nicotinamide therefore improved the capacity of DNA repair. Even a poor diet can fulfill the standard requirement for NAD+ synthesis since NAD+ has various precursors (Belenky et al. 2007). As in the case of pellagra, it is clear it could be harmful in a shortage of NAD, yet it is remains to be seen whether high dosages of NAD precursors can be applicable as a therapeutic or as beneficial diet supplements. This review aims to highlight better understanding of the potential association of nicotinamide on the telomerase activity and telomere length mediated by PARP-1 mechanism particularly in myeloid cancer and to initiate further investigation of tyrosine kinase inhibitors such as nilotinib in relation to nicotinamide supplementation effects.

\section{NICOTINAMIDE AND PARP-1 MECHANISM}

Administration of poly (ADP-ribose) polymerase 1 (PARP-1) has been developed to be one of the promising molecular targets as an anticancer drug where it involves in many biological process from DNA repair to cell death. PARP-1 is also known as NAD+ ADP-ribosyltransferase is a nuclear enzyme encoded by PARP-1 gene which used in DNA damage and repair, where it binds to the DNA single or double strand breaks and used NAD+ as a substrate to form a nicotinamide and ADP-ribose (De Lorenzo et al. 2013; Surjana et al. 2010). One of the earliest events that occur when DNA breaks is the recognition of DNA damage by PARP-1 enzyme (Malyuchenko et al. 2015). DNA breaks will activated the PARP-1 which can lead to three cellular pathways depend on the intensity of DNA damage stimuli (Virag $\&$ Szabo 2002). PARP-1 activation in minimal genotoxic damage will enhance the DNA repair by interacting with 
p53 protein, signaling cell-cycle arrest, and facilitating DNA repair enzymes to access the damaged DNA. PARP-1 activation induces apoptotic cell death when DNA damage is irreparable or stronger damage happened. However, in an extensive DNA damage will cause over activation of PARP-1 that will lead to deplete of intracellular NAD, and therefore, trigger cell to undergo necrosis (Burkle 2001). When the cells are severely deficient in energy, it is unable to proceed through apoptotic cell death since apoptosis is an energy-dependent process (Surjana et al. 2010). Nicotinamide plays an important role in PARP-1 activity for DNA repair and maintenance of the genomic stability and it is related to its function as a NAD+ precursor that involve in many biological processes (Litwack 2018) such as regulation of energy metabolism, DNA repair and transcription.

Inhibition of PARP-1 also currently been studied to act as antitumor agent since PARP-1 inhibitors are able to boost the cytotoxic effects of alkylating agents (Rouleau et al. 2010) which they can enhance the chemo-sensitizers and radio-sensitizers in tumors therapy (Malyuchenko et al. 2015). Inhibition of PARP-1 may lead to the destruction of abnormal cells by suppressing the repair mechanism involved in DNA damage and cause failure to DNA repair. Thus, it will help to increase the effect of alkylating agent in causing breakage of DNA strands and eventually the death of the cell. PARP-1 inhibitors can be used as independent drug against tumors but the inhibitions do not always have direct cytotoxic effect on cell and it can be used with administration of other drug to treated several reported tumor such as in mice lymphoma, Hela cell, and lung cancer cell (Holl et al. 2000; Magan et al. 2012; Mason et al. 2008). Moreover, it also have been reported that one of the PARP-1 inhibitors were shown to prevent recovery of the tumor cell after the potentially lethal damage and surpass the resistance (Liu et al. 2008). Based on Malyuchenko et al. (2015), the first generation of typical PARP-1 inhibitor is nicotinamide which is one of the products of PARP-1 catalyzed reaction that can cause moderate inhibition to its activity. It has been reported in several studies that nicotinamide has inhibit PARP-1 activity (Allende-Castro et al. 2012; Knip et al. 2000; Lee et al. 2008; Park et al. 2010; Virag \& Szabo 2002) in many type of disease and tumors in relation with NAD + and ATP level cause by DNA strand breaks. Therefore, nicotinamide as an inhibitor of PARP-1 plays an important role in determining the cellular fate in response to DNA damage (Turunc Bayrakdar et al. 2014). By inhibition of PARP-1, NAD levels can be manipulated for the therapeutic potential. Since PARP-1 play an important role in detection and repair of both singlestranded and double-stranded DNA breaks, its inhibition has been considered as a treatment to sensitize tumor cells to genotoxic stress such as induced by radiotherapy or chemotherapy. Moreover, telomere stability might also be influenced by PARP-1 activity (Boesten et al. 2013; Paul 2011) and since nicotinamide has been shown as
PARP-1 inhibitor (Kjellen et al. 1985), therefore there might be some association between nicotinamide on the telomerase activity and telomere length mediated by PARP-1 mechanism.

\section{EFFECTS OF NICOTINAMIDE ON TELOMERE AND TELOMERASE IN MYELOID CELLS}

Telomerase activity have been studied and widely explored for their respond toward different kind of drug (Opitz 2005). These enzyme activities and the telomere maintenance are the markers of the proliferative potential of cells and have shown to be involved in cell immortalization and malignant transformation (Shay \& Wright 2004). It is believed that increased telomerase activity found in human cancers prevents telomere length from shorten gradually and this allow the cancer cell to further proliferate out of the normal limits of cellular proliferation (Cao et al. 2008).

Telomere is the repetitive DNA sequence that located at each end of the chromosome in order to maintain the chromosome stability and protect the chromosome from degradation or end-to-end fusion with the nearby chromosome (Bouffler et al. 1996). At each round of cell division, telomeres shorten progressively and according to limit the number of division for a cell to replicate. In the present study, the rate of telomere shortening was reduced in the presence of nicotinamide (Kang et al. 2006) and it is possibly due to the shortening or damaged telomere that will activate the DNA-damage signal to lead to the cell life span extension.

While, telomerase is a ribonucleoprotein enzyme complex consisting of reverse transcriptase (hTERT), protein (hTP1) and RNA template for telomeric DNA synthesis (hTERC). This enzyme stabilizes telomere length and it has been suggested as a useful tumor marker for malignancy. hTERT is the major mechanism to regulate telomerase activity in human cells and in most cancer cells, it is specifically overexpressed (Horikawa $\&$ Barrett 2003; Matsubara et al. 2006). While, telomerase activity is present in over $90 \%$ of human tumors and it is absent in most somatic cells.

According to study by Ida et al. (2009), nicotinic acid related compound including nicotinamide has inhibited the K562 cell proliferation by $50-90 \%$ and also induced differentiation in human acute promyelocytic leukemia HK-60 cells. Other than that, it was also shown to induce apoptosis in human cancer cells (Kauppinen et al. 2013). Several other studies have shown the effect of nicotinamide on the human SIRT1 which was completely inhibited and it leads to reduce the cell proliferation and activated the apoptosis (Audrito et al. 2011; Vaziri et al. 2001). In normal and cancerous cell in existence of damaged DNA will automatically activated the PARP-1 mechanism and by induction of nicotinamide will facilitated the DNA repair process while at the same time also affecting telomerase activity and telomere length regulation (Figure 1). 


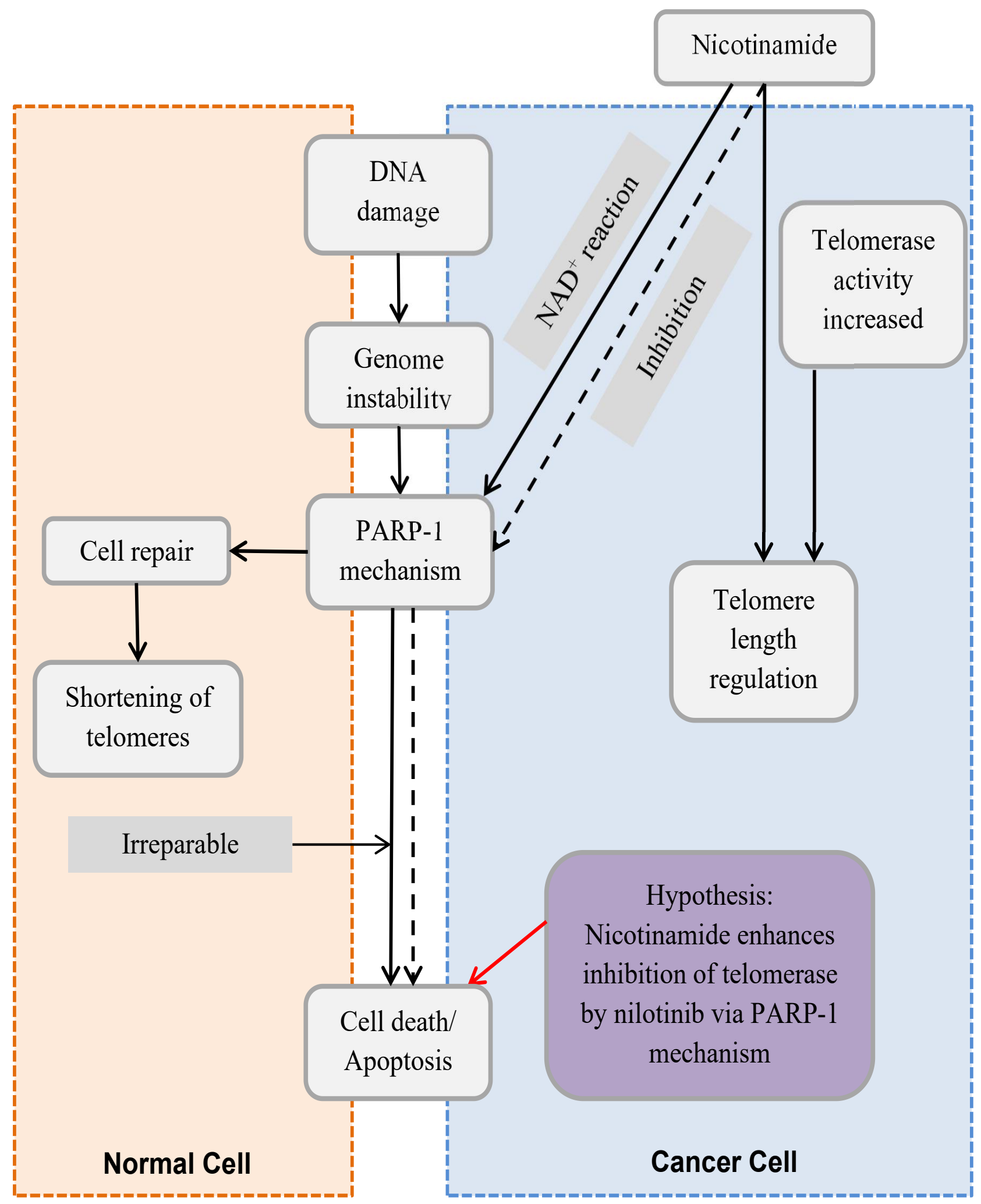

FIGURE 1. Potential effects of nicotinamide towards telomerase and telomere regulation and association with PARP-1 mechanism in normal and cancer cells

K562 cell lines are the human cells that derived from 53 years old female who was a patient with blastic crisis of chronic myelogenous leukemia (CML) (Lozzio $\&$ Lozzio 1975). CML is one of the four major types of 
leukemia disease that affects the myeloid cell. It has been reported as a myeloproliferative disorder due to the reciprocal translocation between chromosome 9 and 22 called Philadelphia chromosome $(\mathrm{Ph})$ that carried by the hematopoietic cell. These $\mathrm{Ph}$ chromosomes encode the BCR-ABL with constitutively active protein tyrosine kinase that is required for cell transformation. The fusion between these two chromosomes forming BCR-ABL oncogene has leading to uncontrolled cellular proliferation and also reduced apoptosis (Hazlehurst et al. 2009). CML cells are unable to function properly to fight infections and disease because they are not fully mature but when the bone marrow produces too much CML cells, it can interfere with the normal cell production and spill out of the bone marrow into the blood stream. It will prevent the bone marrow to make an adequate number of red blood cells, normal white blood cell and platelets that can cause the patient to be more susceptible to anemia, infection or to brushing and bleeding easily.

More than $90 \%$ of patient with CML were found to have the BCR-ABL tyrosine kinase and it cans be as a targeted molecular therapy in order to inhibit the oncogene activity from further proliferate out of control (Druker 2008; Melo \& Barnes 2007; Yildirim et al. 2016). During chronic phase, CML can be effectively treated with tyrosine kinase inhibitor (TKI) which is a type of drug that target the mutant BCR-ABL protein by blocking its effects that have been found in CML cell and it have been approves in clinical trial (Quintas-Cardama et al. 2007). It is referred as molecular targeted therapy due to the specific approach to block the effect of a specific protein that causes transformation of leukemia cell.

The therapy started with imatinib, is widely used as the standard first-line treatment (Druker et al. 2001, 1996; Kantarjian et al. 2002) and has resulted in outstanding responses in the patient. Nevertheless, despite the excellent results with imatinib, a substantial fraction of patients eventually develop resistance to the drug and have to switch to the second-line therapy of TKI such as nilotinib and dasatinib to treat patient who become resistant or intolerant to imatinib (Hughes \& White 2013; Leitner et al. 2011). It is debatably the best example of successful targeted CML treatment.

However, it is continued to exist as a challenging disease in order to treat the CML patient in a blast crisis (BC) phase even though the advance TKI therapy have been introduced (Pietarinen et al. 2015). When the TKI treatment are significantly less effective, it is causing the patient to be less favorably to respond toward the therapy is due to the more aggressive nature of advanced phase of CML. Even the original TKI such as imatinib did not show any toxicity effect to the body after the prolonged contact, but still the intake of imatinib gives several side effects to the patients and by switch the highly potent TKI such as nilotinib and dasatinib also could not be able to improve the overall survival (Hughes \& White
2013). Currently, there is no treatment options that are responding effectively in $\mathrm{CML} \mathrm{BC}$ and it is require an identification of new drug therapies to treat the CML patients in a blast crisis.

A study by Shapira et al. (2012), have shown that the effect of these TKIs on telomerase activity is not necessarily dependent on their effect on BCR-ABL even though the telomerase activity have been reduced by $90 \%$ after been introduced with those TKIs agent compared to the untreated control. They are suggesting that the telomerase is not affected directly by these TKIs but rather through other so far unknown cellular proteins. Nilotinib have shown to have direct effect on telomerase activity where it have been reported to reduce telomerase activity and cause substantial decrease in hTERT expression which is part of enzyme telomerase (Shapira et al. 2012).

\section{CONCLUSION}

The role of nicotinamide as cancer preventive agent will be studied by investigating its effect in enhancing the effect of nilotinib which is the current treatment for patient with resistant to first-line treatment in CML. It has potential as a PARP-1 inhibitor and the ability to decelerate telomere shortening rate without detectable increase in telomerase activity may help to enhance the effect of nilotinib that have shown to have direct effect on telomerase activity. Nicotinamide may boost the effects of nilotinib in K562 cell line and this may reduce the tumor growth or promote the tumor cells death. Therapeutic strategy for CML may be improved by understanding the role and potential of nicotinamide in telomere and telomerase status association with PARP-1 mechanism in myeloid cell line.

\section{ACKNOWLEDGEMENT}

Current study to explore the potential effects of nicotinamide on telomerase activity and telomere length associated by PARP-1 regulation in a myeloid cell line is supported by Fundamental Research Grant Scheme (FRGS) (203.PPSP.6171196) from the Ministry of Higher Education with involvement and collaboration from lecturers in Universiti Sains Malaysia (USM) and Universiti Kebangsaan Malaysia (UKM).

\section{REFERENCES}

Allende-Castro, C., Espina-Marchant, P., Bustamante, D., RojasMancilla, E., Neira, T., Gutierrez-Hernandez, M., Esmar, D. Valdes, J.L., Morales, P., Gebicke-Haerter, P.J. \& HerreraMarschitz, M. 2012. Further studies on the hypothesis of PARP-1 inhibition as a strategy for lessening the longterm effects produced by perinatal asphyxia: Effects of nicotinamide and theophylline on PARP-1 activity in brain and peripheral tissue. Neurotoxicity Research 22(1): 79-90.

Audrito, V., Vaisitti, T., Rossi, D., Gottardi, D., D’Arena, G., Laurenti, L., Gaidano, G., Malavasi, F. \& Deaglio, S. 2011. 
Nicotinamide blocks proliferation and induces apoptosis of chronic lymphocytic leukemia cells through activation of the $\mathrm{p} 53 / \mathrm{miR}-34 \mathrm{a} / \mathrm{SIRT} 1$ tumor suppressor network. Cancer Research 71(13): 4473-4483.

Belenky, P., Bogan, K.L. \& Brenner, C. 2007. NAD+ metabolism in health and disease. Trends in Biochemical Sciences 32(1): 12-19.

Boesten, D.M.P.H.J., de Vos-Houben, J.M.J., Timmermans, L., den Hartog, G.J., Bast, A. \& Hageman, G.J. 2013. Accelerated aging during chronic oxidative stress: A role for PARP-1. Oxidative Medicine and Cellular Longevity 2013: 680414.

Bogan, K.L. \& Brenner, C. 2008. Nicotinic acid, nicotinamide, and nicotinamide riboside: A molecular evaluation of NAD + precursor vitamins in human nutrition. Annu. Rev. Nutr. 28: 115-130.

Bouffler, S.D., Morgan, W.F., Pandita, T.K. \& Slijepcevic, P. 1996. The involvement of telomeric sequences in chromosomal aberrations. Mutation Research/Reviews in Genetic Toxicology 366(2): 129-135.

Burkle, A. 2001. Physiology and pathophysiology of poly (ADP-ribosyl)ation. Bioessays 23(9): 795-806.

Cao, Y., Bryan, T.M. \& Reddel, R.R. 2008. Increased copy number of the TERT and TERC telomerase subunit genes in cancer cells. Cancer Science 99(6): 1092-1099.

Chen, A.C., Martin, A.J., Choy, B., Fernández-Peñas, P., Dalziell, R.A., McKenzie, C.A., Scolyer, R.A., Dhillon, H.M., Vardy, J.L., Kricker, A., St. George, G., Chinniah, N., Halliday, G.M. \& Damian, D.L. 2015. A phase 3 randomized trial of nicotinamide for skin-cancer chemoprevention. New England Journal of Medicine 373(17): 1618-1626.

De Lorenzo, S., Patel, A., Hurley, R. \& Kaufmann, S.H. 2013. The elephant and the blind men: Making sense of PARP inhibitors in homologous recombination deficient tumor cells. Frontiers in Oncology 3: 228.

De Soto, J.A., Wang, X., Tominaga, Y., Wang, R.H., Cao, L., Qiao, W., Cuiling, Li., Xu, X.L., Skoumbourdis, A.P., Prindiville, S.A., Thomas, C.J. \& Deng, C-X. 2006. The inhibition and treatment of breast cancer with poly (ADP-ribose) polymerase (PARP-1) inhibitors. International Journal of Biological Sciences 2(4): 179-185.

Druker, B.J. 2008. Translation of the Philadelphia chromosome into therapy for CML. Blood 112(13): 4808-4817.

Druker, B.J., Talpaz, M., Resta, D.J., Peng, B., Buchdunger, E., Ford, J.M., Lydon, N.B., Kantarjian, H., Capdeville, R., Ohno-Jones, S. \& Sawyers, C.L. 2001. Efficacy and safety of a specific inhibitor of the BCR-ABL tyrosine kinase in chronic myeloid leukemia. New England Journal of Medicine 344(14): 1031-1037.

Druker, B.J., Tamura, S., Buchdunger, E., Ohno, S., Segal, G.M., Fanning, S., Zimmermann, J. \& Lydon, N.B. 1996. Effects of a selective inhibitor of the Abl tyrosine kinase on the growth of Bcr-Abl positive cells. Nature Medicine 2(5): 561-566.

Hazlehurst, L.A., Bewry, N.N., Nair, R.R. \& Pinilla-Ibarz, J. 2009. Signaling networks associated with BCR-ABLdependent transformation. Cancer Control 16(2): 100-107.

Holl, V., Coelho, D., Weltin, D., Hyun, J., Dufour, P. \& Bischoff, P. 2000. Modulation of the antiproliferative activity of anticancer drugs in hematopoietic tumor cell lines by the poly (ADP-ribose) polymerase inhibitor 6 (5H)-phenanthridinone. Anticancer Research 20(5A): 3233-3241.
Horikawa, I. \& Barrett, J.C. 2003. Transcriptional regulation of the telomerase hTERT gene as a target for cellular and viral oncogenic mechanisms. Carcinogenesis 24(7): 1167-1176.

Hughes, T. \& White, D. 2013. Which TKI? An embarrassment of riches for chronic myeloid leukemia patients. $A S H$ Education Program Book 2013 1: 168-175.

Ida, C., Ogata, S., Okumura, K. \& Taguchi, H. 2009. Induction of differentiation in $\mathrm{k} 562$ cell line by nicotinic acid-related compounds. Bioscience, Biotechnology, and Biochemistry 73(1): 79-84.

Jacob, R.A. \& Swendseid, M. 1996. Niacin. Present Knowledge in Nutrition 7: 185-190.

Jacobson, E.L., Shieh, W.M. \& Huang, A.C. 1999. Mapping the role of NAD metabolism in prevention and treatment of carcinogenesis. In ADP-Ribosylation Reactions: From Bacterial Pathogenesis to Cancer, edited by AlvarezGonzalez R. Molecular and Cellular Biochemistry: An International Journal for Chemical Biology in Health and Disease Vol. 30. Boston: Springer. pp. 69-74.

Jin, J., Lee, K.B., Park, S.Y. \& Jang, J.J. 2011. Nicotinamide inhibits hepatic fibrosis by suppressing DNA synthesis and enhancing apoptosis of hepatic stellate cells. Virchows Archive 458(6): 689

Kang, H.T., Lee, H.I. \& Hwang, E.S. 2006. Nicotinamide extends replicative lifespan of human cells. Aging Cell 5(5): 423-436.

Kantarjian, H., Sawyers, C., Hochhaus, A., Guilhot, F., Schiffer, C., Gambacorti-Passerini, C., Niederwieser, D., Resta, D., Capdeville, R., Zoellner, U., Talpaz, M. \& Druker, B. 2002. Hematologic and cytogenetic responses to imatinib mesylate in chronic myelogenous leukemia. New England Journal of Medicine 346(9): 645-652.

Karthikeyan, K. \& Thappa, D.M. 2002. Pellagra and skin. International Journal of Dermatology 41(8): 476-481.

Kauppinen, T.M., Gan, L. \& Swanson, R.A. 2013. Poly (ADPribose) polymerase-1-induced NAD + depletion promotes nuclear factor- $\kappa \mathrm{B}$ transcriptional activity by preventing p65 de-acetylation. Biochimica et Biophysica Acta (BBA)Molecular Cell Research 1833(8): 1985-1991.

Kjellen, E., Jonsson, G.G., Pero, R.W. \& Christensson, P.I. 1985. Effects of hyperthermia and nicotinamide on DNA repair synthesis, ADP-ribosyl transferase activity, NAD+ and ATP pools, and cytotoxicity in $\gamma$-irradiated human mononuclear leukocytes. International Journal of Radiation Biology and Related Studies in Physics, Chemistry and Medicine 49(1): 151-162.

Knip, M., Douek, I.F., Moore, W.P.T., Gillmor, H.A., McLean, A.E.M., Bingley, P.J., Gale, E.A. \& European Nicotinamide Diabetes Intervention Trial Group. 2000. Safety of highdose nicotinamide: A review. Diabetologia 43(11): $1337-$ 1345.

Lee, H.I., Jang, S.Y., Kang, H.T. \& Hwang, E.S. 2008. p53, SIRT1-, and PARP-1-independent downregulation of p21WAF 1 expression in nicotinamide-treated cells. Biochemical and Biophysical Research Communications 368(2): 298-304.

Leitner, A.A., Hochhaus, A. \& Muller, M.C. 2011. Current treatment concepts of CML. Current Cancer Drug Targets 11(1): $31-43$

Litwack, G. 2018. Vitamins and nutrition. In Human Biochemistry, edited by G. Litwack. New York: Academic Press. pp. 645-680. 
Liu, S.K., Coackley, C., Krause, M., Jalali, F., Chan, N. \& Bristow, R.G. 2008. A novel poly (ADP-ribose) polymerase inhibitor, ABT-888, radiosensitizes malignant human cell lines under hypoxia. Radiotherapy and Oncology 88(2): 258-268.

Lozzio, C.B. \& Lozzio, B.B. 1975. Human chronic myelogenous leukemia cell-line with positive Philadelphia chromosome. Blood 45(3): 321-334.

Magan, N., Isaacs, R.J. \& Stowell, K.M. 2012. Treatment with the PARP-inhibitor PJ34 causes enhanced doxorubicinmediated cell death in HeLa cells. Anti-Cancer Drugs 23(6): 627-637.

Malyuchenko, N., Kotova, E.Y., Kulaeva, O., Kirpichnikov, M. \& Studitskiy, V. 2015. PARP1 Inhibitors: Antitumor drug design. Acta Naturae (англоязычная версия) 7(3): 26

Mason, K.A., Valdecanas, D., Hunter, N.R. \& Milas, L. 2008. INO-1001, a novel inhibitor of poly (ADP-ribose) polymerase, enhances tumor response to doxorubicin. Investigational New Drugs 26(1): 1-5.

Matsubara, Y., Murata, M., Yoshida, T., Watanabe, K., Saito, I., Miyaki, K., Kazuyuki, O. \& Ikeda, Y. 2006. Telomere length of normal leukocytes is affected by a functional polymorphism of hTERT. Biochemical and Biophysical Research Communications 341(1): 128-131.

Melo, J.V. \& Barnes, D.J. 2007. Chronic myeloid leukaemia as a model of disease evolution in human cancer. Nature Reviews Cancer 7(6): 441-453.

Opitz, O.G. 2005. Telomeres, telomerase and malignant transformation. Current Molecular Medicine 5(2): 219-226.

Park, J., Halliday, G.M., Surjana, D. \& Damian, D.L. 2010. Nicotinamide prevents ultraviolet radiation-induced cellular energy loss. Photochemistry and Photobiology 86(4): 942-948.

Paul, L. 2011. Diet, nutrition and telomere length. The Journal of Nutritional Biochemistry 22(10): 895-901.

Pietarinen, P., Pemovska, T., Kontro, M., Yadav, B., Mpindi, J., Andersson, E., Majumder, M.M., Kuusanmäki, H., Koskenvesa, P., Kallioniemi, O., Wennerberg, K., Heckman, C.A., Mustjoki, S. \& Porkka, K. 2015. Novel drug candidates for blast phase chronic myeloid leukemia from high-throughput drug sensitivity and resistance testing. Blood Cancer Journal 5(5): e309.

Quintas-Cardama, A., Kantarjian, H. \& Cortes, J. 2007. Flying under the radar: The new wave of BCR-ABL inhibitors. Nature Reviews Drug Discovery 6(10): 834-848.

Ranchoff, R.E. \& Tomecki, K.J. 1986. Niacin or niacinamide? Nicotinic acid or nicotinamide? What is the difference? Journal of the American Academy of Dermatology 15(1): 116-117.

Rouleau, M., Patel, A., Hendzel, M.J., Kaufmann, S.H. \& Poirier, G.G. 2010. PARP inhibition: PARP1 and beyond. Nature Reviews Cancer 10(4): 293-301.

Shapira, S., Granot, G., Mor-Tzuntz, R., Raanani, P., Uziel, O., Lahav, M. \& Shpilberg, O. 2012. Second-generation tyrosine kinase inhibitors reduce telomerase activity in K562 cells. Cancer Letters 323(2): 223-231.

Shay, J.W. \& Wright, W.E. 2004. Senescence and immortalization: Role of telomeres and telomerase. Carcinogenesis 26(5): 867-874.

Surjana, D., Halliday, G.M. \& Damian, D.L. 2010. Role of nicotinamide in DNA damage, mutagenesis, and DNA repair. Journal of Nucleic Acids 2010: 157591.
Surjana, D., Halliday, G.M. \& Damian, D.L. 2013. Nicotinamide enhances repair of ultraviolet radiationinduced DNA damage in human keratinocytes and ex vivo skin. Carcinogenesis 34(5): 1144-1149.

Thompson, B.C., Surjana, D., Halliday, G.M. \& Damian, D.L. 2014. Nicotinamide enhances repair of ultraviolet radiation-induced DNA damage in primary melanocytes. Experimental Dermatology 23(7): 509-511.

Traister, A., Breitman, I., Bar-Lev, E., Zvibel, I., Harel, A., Halpern, Z. \& Oren, R. 2005. Nicotinamide induces apoptosis and reduces collagen I and pro-inflammatory cytokines expression in rat hepatic stellate cells. Scandinavian Journal of Gastroenterology 40(10): 12261234.

Turunc Bayrakdar, E., Uyanikgil, Y., Kanit, L., Koylu, E. \& Yalcin, A. 2014. Nicotinamide treatment reduces the levels of oxidative stress, apoptosis, and PARP-1 activity in A $\beta$ (1-42)-induced rat model of Alzheimer's disease. Free Radical Research 48(2): 146-158.

Vaziri, H., Dessain, S.K., Eaton, E.N., Imai, S.I., Frye, R.A., Pandita, T.K., Guarente, L. \& Weinberg, R.A 2001. hSIR2SIRT1 functions as an NAD-dependent p53 deacetylase. Cell 107(2): 149-159.

Virag, L. \& Szabo, C. 2002. The therapeutic potential of poly (ADP-ribose) polymerase inhibitors. Pharmacological Reviews 54(3): 375-429.

Yarosh, D.B. 2004. DNA repair, immunosuppression, and skin cancer. Cutis. 74(5): 10-13.

Yildirim, R., Sincan, G., Pala, C., Dudukcu, M., Kaynar, L., Urlu, S.M., Kiki, İ., Erdem, F., Çetin, M., Gündoğdu, M. \& Topdağ1, Ö. 2016. Effects of imatinib, nilotinib and dasatinib on serum VEGF and VEGFR-1 levels in patients with chronic phase chronic myelogenous leukemia. European Journal of General Medicine 13(2): 111-115.

Nur Rasyidah Muhammad \& Sarina Sulong*

Human Genome Centre

School of Medical Sciences

Universiti Sains Malaysia

Health Campus, 16150 Kelantan Darul Naim

Malaysia

Azlina Ahmad

School of Dental Sciences

Universiti Sains Malaysia

Health Campus, 16150 Kelantan Darul Naim

Malaysia

Siti Norasikin Mohd Nafi

Department of Pathology

School of Medical Sciences

Universiti Sains Malaysia

Health Campus, 16150 Kelantan Darul Naim

Malaysia

Farizan Ahmad

Department of Neurosciences

School of Medical Sciences

Universiti Sains Malaysia

Health Campus, 16150 Kelantan Darul Naim

Malaysia 
Zariyantey Abdul Hamid

School of Diagnostic and Applied Health Sciences

Faculty of Health Sciences

Universiti Kebangsaan Malaysia

50300 Kuala Lumpur, Federal Territory

Malaysia
*Corresponding author; email: ssarina@usm.my

Received: 21 April 2019

Accepted: 7 January 2020 